\title{
Linking environmental drivers with amphibian species diversity in ponds from subtropical grasslands
}

\author{
DARLENE S. GONÇALVES ${ }^{1}$, LUCAS B. CRIVELLARI ${ }^{2}$ \\ and CARLOS EDUARDO CONTE ${ }^{3 *, 4}$ \\ ${ }^{1}$ Programa de Pós-Graduação em Zoologia, Universidade Federal do Paraná, \\ Caixa Postal 19020, 81531-980 Curitiba, PR, Brasil \\ ${ }^{2}$ Programa de Pós-Graduação em Biologia Animal, Universidade Estadual Paulista, \\ Rua Cristovão Colombo, 2265, Jardim Nazareth, 15054-000 São José do Rio Preto, SP, Brasil \\ ${ }^{3}$ Universidade Federal do Paraná. Departamento de Zoologia, Caixa Postal 19020, 81531-980 Curitiba, PR, Brasil \\ ${ }^{4}$ Instituto Neotropical: Pesquisa e Conservação. Rua Purus, 33, 82520-750 Curitiba, PR, Brasil
}

Manuscript received on September 17, 2014; accepted for publication on March 2, 2015

\begin{abstract}
Amphibian distribution patterns are known to be influenced by habitat diversity at breeding sites. Thus, breeding sites variability and how such variability influences anuran diversity is important. Here, we examine which characteristics at breeding sites are most influential on anuran diversity in grasslands associated with Araucaria forest, southern Brazil, especially in places at risk due to anthropic activities. We evaluate the associations between habitat heterogeneity and anuran species diversity in nine body of water from September 2008 to March 2010, in 12 field campaigns in which 16 species of anurans were found. Of the seven habitat descriptors we examined, water depth, pond surface area and distance to the nearest forest fragment explained $81 \%$ of total species diversity. Water depth, margin vegetation type, surface area and distance to the next body of water explained between $31-74 \%$ of the variance in abundance of nine of the 16 species. Thus, maintenance of body of water, of the vegetation along the water edge and natural forest fragments in the grasslands, along with fire control (used to renovation of pasture), are fundamentally important for the maintenance of anuran species diversity through the conservation of their breeding sites.
\end{abstract}

Key words: conservation, environmental variables, generalized linear models, hierarchical partitioning.

\section{INTRODUCTION}

Understanding processes, both biotic and abiotic, that generate patterns of species' distributions and the diversity that is a consequence of those processes is fundamental for community ecology (Huston 1994,

Correspondence to: Darlene da Silva Gonçalves

E-mail: darlene.goncalves@gmail.com /

darlene_sg@yahoo.com.br

*Bolsista PNPD
Hutchinson 1959). Environmental heterogeneity at many scales is also important (Hamer and Parris 2011, Richter-Boix et al. 2007, Shulse et al. 2010, Silva et al. 2011a, 2012, Werner et al. 2009). Complex environments tend to have more microhabitats that allow differential resource use thereby favoring species coexistence (Campos and Vaz-Silva 2010, Cardoso et al. 1989, Conte and Rossa-Feres 2007, Rossa-Feres and Jim 2001, Vasconcelos et al. 2009). 
In frogs, the study of environmental heterogeneity and its influence on diversity has been useful in explaining landscape and local (body of water) distribution of species during the reproductive period. Local scale environmental characteristics studied include timing of water availability (Babbit 2005, Egan and Paton 2004, Lichtenberg et al. 2006, Richter-Boix et al. 2007, Santos et al. 2007, Vasconcelos et al. 2009), water depth (Babbit 2005, Babbit and Turner 2000, Burne and Griffin 2005), area (Afonso and Eterovick 2007, Burne and Griffin 2005, Keller et al. 2009, Parris 2004, Parris and McCarthy 1999) and vegetation in and around the body of water (Burne and Griffin 2005, Keller et al. 2009, Vasconcelos et al. 2009). Landscape scale factors usually include distance to forest fragments (Herrmann et al. 2005, Laan and Verboom 1990, Silva and Rossa-Feres 2007, 2011, Silva et al. 2011a, b) and distance between bodies of water (Burne and Griffin 2005). While understanding these factors is important for ecology and conservation (Silva et al. 2011), it is impossible to define just one relationship, since each location has both different species and different combinations of environmental features (Hazell et al. 2001, Vasconcelos et al. 2009).

Few studies have examined frog community structure in subtropical grasslands (review in Souza-Filho and Conte 2010), none of which examined environmental influences on occurrence. Subtropical grassland vegetation is a relict of a previous, drier period before the formation of Araucaria Forests and so has a variety of plants adapted to periods of hot weather (Behling 2002, Behling and Pillar 2007, Klein 1960, Maack 2012, Overbeck et al. 2007). Today, agriculture has reduced the extent of these subtropical grasslands to a much smaller area than they originally covered (Behling and Pillar 2007, Medeiros et al. 2005, Overbeck et al. 2007). This reduction is often due to periodic burning (to improve pasture), plowing for planting and the introduction of exotic trees, all of which change the original patterns of nutrient and water cycling (GISP 2005, Guimarães et al. 2010, Medeiros et al. 2005). Also, grasslands get very little attention in terms of conservation (Overbeck et al. 2007, Pillar et al. 2009), and so today it is urgent that these areas be studied for both an ecological understanding and for conservation and maintenance of diversity of anuran communities (Beja and Alcazar 2003, Hazell et al. 2001, Silva et al. 2011a, 2012). Thus, here we examine how environmental variation at local and larger scales influences diversity of frogs in bodies of water in subtropical grasslands.

\section{MATERIALS AND METHODS}

STUDY AREA

Subtropical grasslands are common in southern Brazil, where are located in the Pampa biome and in the Atlantic Forest biome forming mosaics with Araucaria forest, within which the Palmas Grasslands is found (Overbeck 2007, Pillar and Vélez 2010, Maack 2012). The original grasslands of Palmas comprised 2,350 $\mathrm{km}^{2}$ and had many small patches of riverine mixed rainforests (capão) along with isolated remnants of Araucaria forests scattered in the grasslands (Maack 2012). Today, grasslands are threatened due to a variety of activities, such as conversion to pasture (and burning to renew the pasture) as well as for pine and eucalyptus plantations (Behling and Pillar 2007, Medeiros et al. 2005, Overbeck et al. 2007).

Frogs were studied at the Campos de Palmas Wildlife Refuge (16,600ha, 26³1'40”S, 51'36'17'W) in Palmas and General Carneiro, in southern Brazil (Fig. 1). The climate is temperate, with mild summers and no well-defined rainy season (IAPAR 2014), and rainfall is about $1800 \mathrm{~mm} \mathrm{yr}^{-1}$, average relative humidity at $70 \%$ and average temperature of $16^{\circ} \mathrm{C}$.

\section{FIELD STUDY}

We searched for frogs at nine ponds during 12, 2-day field campaigns during two breeding seasons: September 2008 to April 2009 and September 2009 


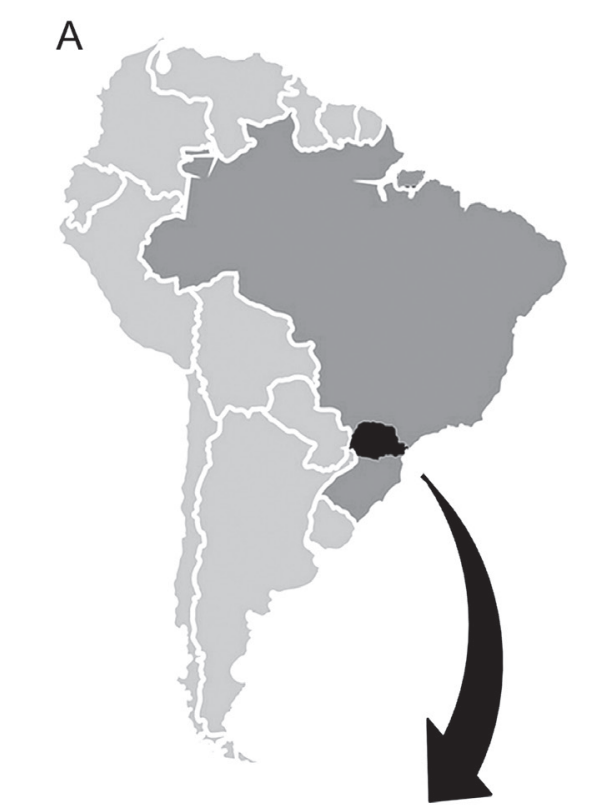

C
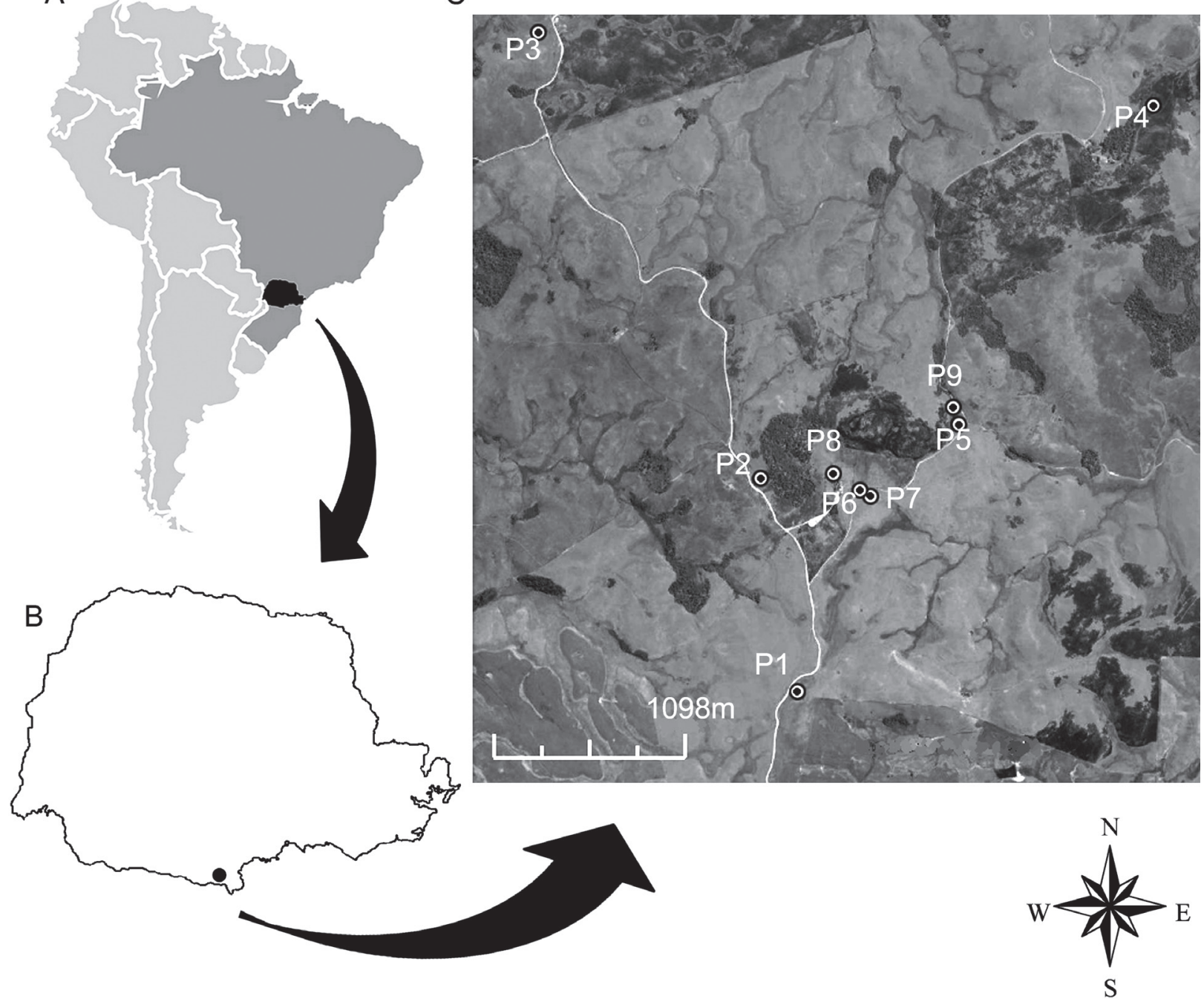

Figure 1 - Map of South America (a) with Paraná highlighted (b) and satellite imagery of sampling locations (c) in a subtropical natural field landscape. Image adapted from Google Earth.

to March 2010 (Table I). We counted frogs between the hours of 18:00 - 23:00 h by active search at breeding sites, following Scott Jr and Woodward (1994). We walked slowly along the perimeter of the pond, noting all individuals seen and males heard while vocalizing. During each count, we visited ponds randomly and switched directions in each visit to avoid bias (Conte and Rossa-Feres 2006).

In October 2008 and 2009, at each pond we measured four environmental variables to test for the influence of environmental variability:
AREA - maximum pond surface area $\left(\mathrm{m}^{2}\right)$, PVEI - emergent vegetation (as percent cover of the pond surface area), DEPT - maximum pond depth (cm), and VEGE - vegetation bordering the pond (herbaceous, shrub, tree and), $1=$ only one type of vegetation, 2 = two type of vegetation, $3=$ three type of vegetation. We measured these variables in October because it is historically the month with the greatest rainfall and anuran density (Conte and Rossa-Feres 2006, 2007). The hydroperiod (HYDR) as analyzed throughout the entire field 
TABLE I

Characterization of bodies of water in natural fields in a subtropical field landscape from September 2008 to April 2009 and September 2009 to March 2010.

\begin{tabular}{cccccccc}
\hline Point & Longitude & Latitude & Season & Veg & Depth $(\mathrm{cm})$ & Area $\left(\mathrm{m}^{2}\right)$ & PVEI $(\%)$ \\
\hline 1 & -51.661306 & -26.555667 & Short & H, S, T & 40 & 900 & 20 \\
2 & -51.663389 & -26.545028 & Short & H, S, T & 40 & 1980 & 40 \\
3 & -51.676000 & -26.522556 & Long & H, S & 80 & 1440 & 80 \\
4 & -51.641250 & -26.526139 & Short & H & 20 & 408 & 5 \\
5 & -51.652306 & -26.542333 & Long & H, S & 80 & 896 & 60 \\
6 & -51.658222 & -26.545861 & Short & H, S & 40 & 480 & 20 \\
7 & -51.657250 & -26.545944 & Short & H, S & 30 & 300 & 5 \\
8 & -51.659444 & -26.544750 & Long & H, S, T & 50 & 600 & 30 \\
9 & -51.65261 & -26.54147 & Long & H, S, T & 20 & 35 & 30 \\
\hline
\end{tabular}

$\mathrm{H}$ - herbaceous; $\mathrm{S}$ - shrubs; $\mathrm{T}$ - tress; P1 to P8 are temporary ponds and P9 is a marshy area next to a stream. Environmental variables: Season is length of hydroperiod; Veg - type of vegetation surrounding the body of water; Depth (cm) - pond depth; Area $\left(\mathrm{m}^{2}\right)$ - surface area of the pond and PVEI $(\%)$ - percent emergent vegetation inside the body of water.

work and was classified as short $(<6 \mathrm{mo})$ or long (>6 mo). We also measured larger scale features: CFFD - distance to nearest forest fragment and CBPD - distance to nearest pond.

\section{DATA ANALYSIS}

We tested for spatial autocorrelation among environmental variables using Moran's I and the program Spatial Analysis in Macroecology v. 3.0 (SAM, Rangel et al. 2006) and considered variance inflation factors (VIF) $>3$ to indicate colinearity and we removed such variables from the analysis, following Zuur et al. (2009).

To evaluate the influence of environmental variables on the richness we fitted generalized linear models (GLMs, McCullagh and Nelder 1989) to the data using the GLM function implemented in the statistical package NLME (Pinheiro et al. 2012, R Development Core Team 2012). Since our data were not overdispersed, the analyses were carried out with Poisson distribution and log link function. To determine the optimal model, we started with a model in which the fixed component contained all explanatory variables. We used Akaike's information criterion, corrected for small sample sizes (AICc, Burnham and Anderson 1998), to select explanatory variables that were driving total species richness. We used Akaike weights to evaluate model-selection uncertainty.

We tested for the influence of environmental variables on frog species richness and abundance (the sum of all individuals found in all the campaigns) using generalized linear models using the Poisson distribution (GLM; McCullagh and Nelder 1989) and compared models using Akaike Information Criterion (AIC, Burnham and Anderson 2002) using the statistical package NLME (Pinheiro et al. 2012, R Development Core Team 2012). We detected overdispersion and corrected using the negative binomial distribution and log-link function with the MASS package in R (Venables and Ripley 2002, Zuur et al. 2009). We evaluated the deviance explained and weight by each model to determine the optimal model best explaining habitat variables driving total species abundance.

We determined which environmental variables were most important for frog abundance by species (for those with $>25$ individuals), using an analysis of hierarchical partitioning (Mac Nally 2002) using the statistical package hier.part (Walsh and Mac Nally 2008) in R. This hierarchical analysis compares all possible models of the effects of 
independent environmental variables on abundance (the dependent variable) and then estimates the strength of the contribution of each variable and groups of variables (Chevan and Sutherland 1991, Mac Nally 1996, 2000).

\section{RESULTS}

We recorded 16 species belonging to five families: Bufonidae, Hylidae, Leptodactylidae, Microhylidae and Odontophrynidae (Table II). Both emergent PVEI and HYDR had VIF $>3$ and were removed from further analysis. Three out of 16 species had abundance below 25 individuals and, therefore, were not analyzed.

None of the explanatory variables predicted total species richness well: DEPT (likelihood ratio test, all $\left.\mathrm{df}=1, \chi^{2}=0.33, \mathrm{P}=0.56\right)$, VEGE $\left(\chi^{2}=\right.$ $0.12, \mathrm{P}=0.72), \operatorname{AREA}\left(\chi^{2}=0.085, \mathrm{P}=0.76\right), \mathrm{CFFD}$ $\left(\chi^{2}=0.05, \mathrm{P}=0.81\right), \operatorname{CBPD}\left(\chi^{2}=0.01, \mathrm{P}=0.89\right)$.
However, larger and deeper ponds that were closer to forest fragments had greater anuran diversity. Of the five environmental variables analyzed, the model with AREA, DEPT and CFFD was the most parsimonious and explained $81 \%$ of the total variation of species abundance (Table III).

Four environmental variables (AREA, DEPT, CBPD and VEGE) explained from $31 \%$ to $74 \%$ of the total variation in species abundance of nine species in bodies of water (Table IV, Fig. 2): Dendropsophus minutus, Hypsiboas prasinus and Physalaemus aff. gracilis with AREA; Pseudis cardosoi and Leptodactylus cf. latrans com DEPT; Scinax squalirostris and Physalaemus cuvieri with DEPT and AREA; Scinax uruguayus with CBPD; Hypsiboas leptolineatus with VEGE. The distributions of Rhinella icterica, Scinax granulatus, Leptodactylus plaumanni and Elachistocleis bicolor were not related to the environmental variables analyzed.

TABLE II

List of species, abundance and occurrence in bodies of water between September 2008 and April 2009 and September 2009 and March 2010 in a subtropical landscape of natural fields.

\begin{tabular}{|c|c|c|c|c|c|c|c|c|c|}
\hline & $\mathrm{P} 1$ & $\mathrm{P} 2$ & P3 & $\mathrm{P} 4$ & P5 & P6 & P7 & P8 & P9 \\
\hline \multicolumn{10}{|l|}{ Bufonidae } \\
\hline Rhinella icterica (Spix, 1824) & & & & 8 & & 10 & 2 & 4 & 1 \\
\hline \multicolumn{10}{|l|}{ Hylidae } \\
\hline Aplastodiscus perviridis A. Lutz in B. Lutz, 1950 & & 1 & 3 & & & 3 & & & 13 \\
\hline Dendropsophus minutus (Peters, 1872) & 71 & 556 & 372 & 12 & 122 & 14 & 7 & 183 & 8 \\
\hline Hypsiboas leptolineatus (P. Braun \& C. Braun, 1977) & & 1 & & & 3 & & & & 68 \\
\hline Hypsiboas prasinus (Burmeister, 1856) & 19 & 41 & 29 & & 2 & & 4 & 8 & 1 \\
\hline Pseudis cardosoi Kwet, 2000 & & & 98 & & 1 & & & 3 & \\
\hline Scinax aromothyella Faivovich, 2005 & & & 5 & 2 & & & & & \\
\hline Scinax granulatus (Peters, 1871) & 47 & 160 & 138 & 7 & 63 & 12 & 44 & 240 & \\
\hline Scinax squalirostris (A. Lutz, 1925) & 34 & 98 & 191 & 11 & 74 & 3 & 29 & 43 & 4 \\
\hline Scinax uruguayus (Schmidt, 1944) & 216 & 107 & 32 & 24 & 3 & 11 & 145 & 160 & \\
\hline \multicolumn{10}{|l|}{ Leptodactylidae } \\
\hline Physalaemus cuvieri Fitzinger, 1826 & 26 & 43 & 229 & 4 & 60 & 22 & 4 & 46 & 3 \\
\hline Physalaemus aff. gracilis & 11 & 18 & 5 & 3 & 4 & & & 4 & 1 \\
\hline Leptodactylus plaumanni Ahl, 1936 & 6 & 9 & 3 & 9 & & 2 & 1 & 9 & \\
\hline Leptodactylus cf. latrans & 2 & 6 & 13 & 2 & 21 & 7 & 3 & 10 & 6 \\
\hline \multicolumn{10}{|l|}{ Microhylidae } \\
\hline Elachistocleis bicolor (Valenciennes in Guérin-Menéville, 1838) & 11 & & 12 & & & 3 & 1 & 15 & \\
\hline \multicolumn{10}{|l|}{ Odontophrynidae } \\
\hline Odontophrynus americanus (Duméril \& Bibron, 1841) & 1 & & 1 & 7 & 2 & & & & \\
\hline
\end{tabular}


TABLE III

Generalized linear models used to analyze the influence of environmental heterogeneity on species distribution in bodies of water in a landscape of natural fields from September 2008 to April 2009 and from September 2009 to March 2010.

\begin{tabular}{lcccc}
\hline \multicolumn{1}{c}{ Models } & $\Delta$ AIC & $\mathbf{k}$ & wAIC & \% DEV \\
\hline DEPT + AREA + CFFD & 0 & 4 & 0.4 & 81 \\
DEPT + AREA + CFFD + CBPD & 0.2 & 5 & 0.3 & 84 \\
DEPT + VEGE + AREA + CFFD + CBPD & 1.8 & 6 & 0.2 & 85 \\
DEPT + CFFD & 2.9 & 3 & 0.1 & 68 \\
DEPT & 8.4 & 2 & 0 & 32 \\
\hline
\end{tabular}

$\triangle \mathrm{AIC}$ - AIC information criterion for each model from the most parsimonious; $\mathrm{k}=$ number of parameters; wAIC - AIC weights for each model; \% DEV percent variance explanation.

\section{DISCUSSION}

Anuran diversity and the presence of some species in natural fields were affected by both local characteristics of the body of water (such as area, type of vegetation around the body of water and water depth) and larger scale features (such as distance from the nearest fragment and distance from the nearest body of water). Environmental characteristics (vegetation, area and depth) determine habitat heterogeneity as a consequence of structural complexity of bodies of water and determine the availability of microhabitats used by anurans as sites for calling and egg-laying during the breeding period (Afonso and Eterovick 2007, Bastazini et al. 2007, Burne and Griffin 2005, Silva et al. 2012, Vasconcelos et al. 2009).

The effects of solar incidence on open areas waterbodies are reduced by a larger pond area and depth (higher water storage). This decreases evaporation and the risk of rapid droughts (dessication), reducing environmental unpredictability during the larval period and until the end of metamorphosis (Parris and McCarthy 1999, Laan and Verboom 1990, Parris 2004, Babbit 2005, Santos et al. 2007). Greater predictability of water availability is important for reproductive success in species of anurans with prolonged reproduction, such as Leptodactylus cf. latrans and Physalaemus cuvieri (Conte and Rossa-
Feres 2006), and species that use deeper areas for calling and egg-laying, such as Pseudis cardosoi (Kwet 2000, Conte et al. 2010). Nonetheless, larger area (especially if depth does not increase) can result in more vegetation both in and around the body of water. This increased vegetation favors the segregation of arboreal species that use vertical call sites, which reduces the number of physical confrontations and agonistic interactions in the dispute over females and calling sites (e.g. D. minutus, H. prasinus, H. leptolineatus and S. squalirostris; Cardoso and Haddad 1984, Cardoso et al. 1989, Conte and Machado 2005, Pombal Jr and Haddad 2005, Rossa-Feres and Jim 2001, Wells 2007). Increased vegetation also provides microhabitat for terrestrial species that vocalize from the shore, shallow areas or in cavities covered by vegetation (e.g. P. aff. gracilis; Conte and Machado 2005). Vegetation protects egg masses from desiccation and predation and can result in increased survival for larvae, for individuals metamorphosing into the adult stage and for adults that use this vegetation as shelter from predators and extreme temperatures during the breeding season (Hazell et al. 2001).

Although the frogs in this study are found mainly in association with open areas, nearness to the forest fragment was associated with greater diversity and may be a consequence of greater 

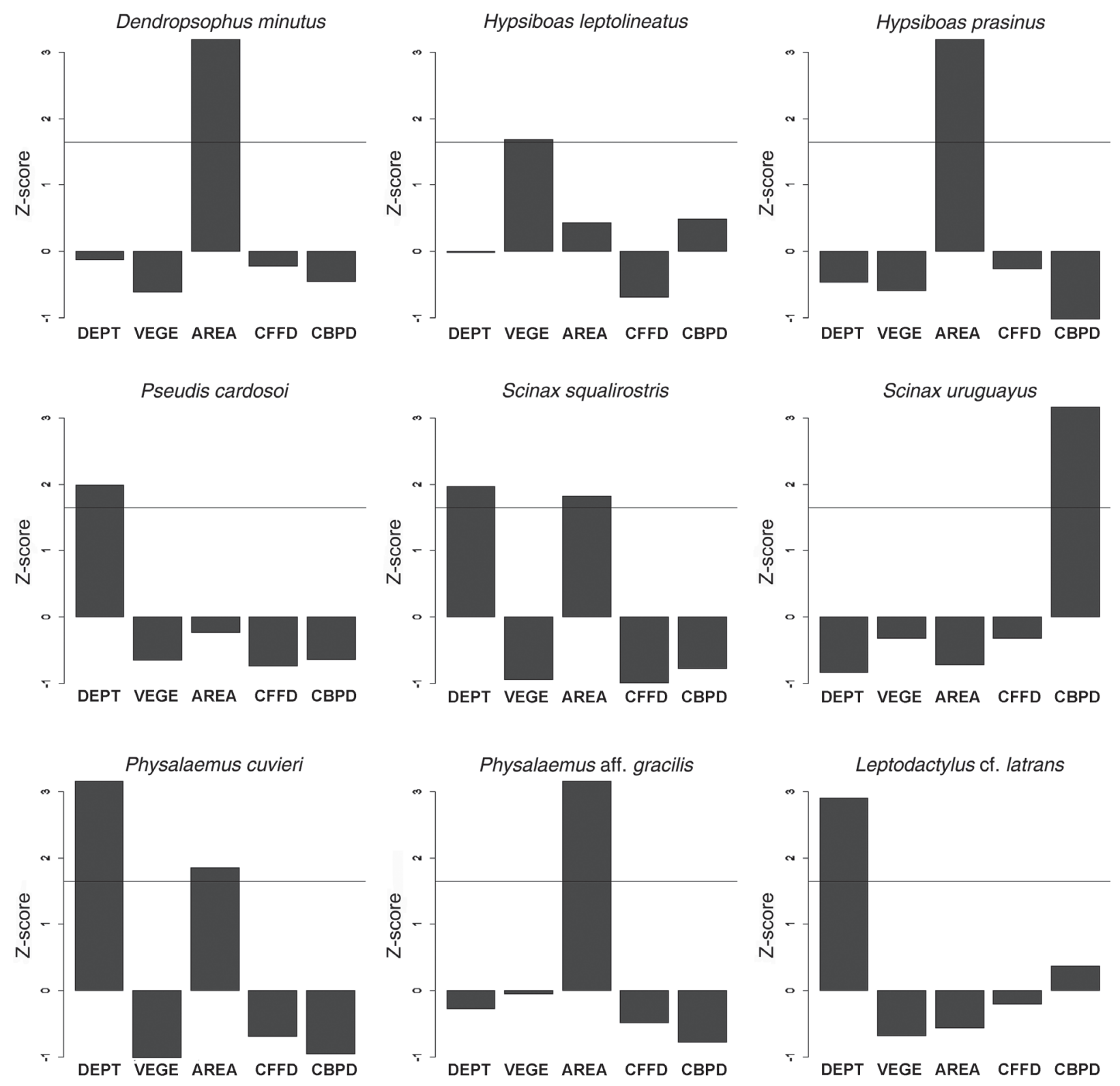

Figure 2 - Independent contributions of environmental variables to abundance of nine species sampled in natural fields of a subtropical natural field landscape from September 2008 to April 2009 and from September 2009 to March 2010. Bars are Z-scores that indicate the independent contribution of each variable based on randomization and possible predictor variables that explain species abundances. The horizontal line is the $95 \%$ confidence interval and bars above the line indicate statistical importance. DEPT - depth; VEGE - vegetation type (herbaceous, shrubby or arboreal) around the body of water and AREA - area in $\mathrm{m}^{2}$; CFFD - distance to nearest forest fragment and CBPD - distance to nearest body of water.

availability of resources, such as areas for juvenile dispersal when open breeding areas are at risk of desiccation (Rothermel 2004, Rothermel and Semlitsch 2002, Silva and Rossa-Feres 2007), refuges during the dry season for both juveniles and adults (Silva and Rossa-Feres 2007), day-time shelter during the breeding season or foraging locations (Silva and Rossa-Feres 2007), and more stable levels of humidity closer to forest fragments (Silva and Rossa-Feres 2007, 2011). 
TABLE IV

Hierarchical partition correlating the abundance of 14 anuran species sampled in natural fields of a subtropical natural field landscape from September 2008 to April 2009 and from September 2009 to March 2010.

\begin{tabular}{|c|c|c|c|c|c|c|c|c|c|c|c|c|c|c|}
\hline \multicolumn{5}{|c|}{ Rhinella icterica } & \multicolumn{5}{|c|}{ Aplastodiscus perviridis } & \multicolumn{5}{|c|}{ Dendropsophus minutus } \\
\hline & I & $\mathrm{J}$ & $\mathrm{R}^{2}$ & Z-score & & I & $\mathrm{J}$ & $\mathrm{R}^{2}$ & Z-score & & I & $\mathrm{J}$ & $\mathrm{R}^{2}$ & Z-score \\
\hline DEPT & 0.09 & 0.07 & 14.33 & -0.27 & DEPT & 0.06 & 0.03 & 9.26 & -0.54 & DEPT & 0.11 & 0.08 & 11.31 & -0.13 \\
\hline VEGE & 0.30 & -0.02 & 47.20 & 1.3 & VEGE & 0.17 & -0.07 & 24.71 & 0.42 & VEGE & 0.05 & 0.06 & 5.12 & -0.61 \\
\hline AREA & 0.13 & 0.08 & 20.83 & 0.03 & AREA & 0.15 & -0.02 & 22.46 & 0.32 & AREA & 0.65 & 0.23 & 67.00 & 4.22 \\
\hline CFFD & 0.08 & -0.08 & 12.89 & -0.53 & CFFD & 0.03 & -0.01 & 3.98 & -0.77 & CFFD & 0.09 & 0.03 & 9.40 & -0.22 \\
\hline CBPD & 0.03 & 0.00 & 4.75 & -0.78 & CBPD & 0.27 & -0.13 & 39.59 & 1.3 & CBPD & 0.07 & -0.01 & 7.16 & -0.46 \\
\hline \multicolumn{5}{|c|}{ Hypsiboas leptolineatus } & \multicolumn{5}{|c|}{ Hypsiboas prasinus } & \multicolumn{5}{|c|}{ Pseudis cardosoi } \\
\hline & I & $\mathrm{J}$ & $\mathrm{R}^{2}$ & Z-score & & I & $\mathrm{J}$ & $\mathrm{R}^{2}$ & Z-score & & I & $\mathrm{J}$ & $\mathrm{R}^{2}$ & Z-score \\
\hline DEPT & 0.11 & 0.03 & 14.26 & -0.02 & DEPT & 0.07 & 0.02 & 7.55 & -0.47 & DEPT & 0.30 & 0.07 & 58.89 & 1.99 \\
\hline VEGE & 0.26 & -0.13 & 32.21 & 1.69 & VEGE & 0.07 & 0.10 & 7.08 & -0.59 & VEGE & 0.05 & -0.02 & 10.26 & -0.65 \\
\hline AREA & 0.20 & 0.01 & 24.36 & 0.43 & AREA & 0.70 & 0.15 & 74.88 & 4.72 & AREA & 0.09 & 0.08 & 17.48 & -0.23 \\
\hline CFFD & 0.04 & -0.03 & 4.56 & -0.69 & CFFD & 0.09 & 0.08 & 9.79 & -0.26 & CFFD & 0.04 & -0.03 & 7.21 & -0.74 \\
\hline CBPD & 0.20 & -0.11 & 24.61 & 0.49 & CBPD & 0.01 & 0.00 & 0.70 & -1.02 & CBPD & 0.03 & 0.03 & 6.15 & -0.64 \\
\hline \multicolumn{5}{|c|}{ Scinax granulatus } & \multicolumn{5}{|c|}{ Scinax squalirostris } & \multicolumn{5}{|c|}{ Scinax uruguayus } \\
\hline & I & $\mathrm{J}$ & $\mathrm{R}^{2}$ & Z-score & & I & $\mathrm{J}$ & $\mathrm{R}^{2}$ & Z-score & & I & $\mathrm{J}$ & $\mathrm{R}^{2}$ & Z-score \\
\hline DEPT & 0.19 & 0.02 & 30.97 & 0.86 & DEPT & 0.38 & 0.21 & 46.90 & & DEPT & 0.01 & 0.01 & 1.41 & -0.84 \\
\hline VEGE & 0.09 & 0.10 & 14.54 & -0.55 & VEGE & 0.01 & -0.01 & 1.18 & -0.95 & VEGE & 0.10 & 0.15 & 10.86 & -0.32 \\
\hline AREA & 0.16 & 0.16 & 25.53 & -0.85 & AREA & 0.37 & 0.22 & 45.99 & 1.82 & AREA & 0.04 & -0.01 & 4.17 & -0.72 \\
\hline CFFD & 0.17 & 0.03 & 27.87 & -0.41 & CFFD & 0.02 & -0.02 & 2.31 & -0.99 & CFFD & 0.09 & 0.15 & 9.66 & -0.32 \\
\hline CBPD & 0.01 & -0.01 & 1.10 & 0.01 & CBPD & 0.03 & 0.03 & 3.63 & -0.78 & CBPD & 0.65 & 0.13 & 73.91 & 5.59 \\
\hline \multicolumn{5}{|c|}{ Physalaemus aff. gracilis } & \multicolumn{5}{|c|}{ Physalaemus cuvieri } & \multicolumn{5}{|c|}{ Leptodatylus plaumanni } \\
\hline & I & $\mathrm{J}$ & $\mathrm{R}^{2}$ & Z-score & & I & $\mathrm{J}$ & $\mathrm{R}^{2}$ & Z-score & & I & $\mathrm{J}$ & $\mathrm{R}^{2}$ & Z-score \\
\hline DEPT & 0.08 & -0.07 & 8.42 & -0.27 & DEPT & 0.59 & 0.21 & 62.90 & 4.16 & DEPT & 0.11 & -0.07 & 28.66 & -0.08 \\
\hline VEGE & 0.13 & 0.09 & 13.59 & -0.05 & VEGE & 0.02 & 0.01 & 1.84 & -1.01 & VEGE & 0.01 & 0.00 & 2.49 & -0.96 \\
\hline AREA & 0.70 & 0.00 & 71.51 & 5.48 & AREA & 0.30 & 0.25 & 31.62 & 1.85 & AREA & 0.23 & -0.08 & 56.45 & 1.11 \\
\hline CFFD & 0.05 & 0.03 & 4.85 & -0.49 & CFFD & 0.03 & -0.03 & 2.68 & -0.69 & CFFD & 0.04 & 0.03 & 10.85 & -0.73 \\
\hline CBPD & 0.02 & 0.00 & 1.63 & -0.78 & CBPD & 0.01 & 0.01 & 0.96 & -0.96 & CBPD & 0.01 & 0.00 & 1.55 & -1 \\
\hline \multicolumn{5}{|c|}{ Leptodactylus cf. latrans } & \multicolumn{5}{|c|}{ Elachistocleis bicolor } & & & & & \\
\hline & I & $\mathrm{J}$ & $\mathrm{R}^{2}$ & Z-score & & I & $\mathrm{J}$ & $\mathrm{R}^{2}$ & Z-score & & & & & \\
\hline DEPT & 0.59 & 0.16 & 63.08 & 2.9 & DEPT & 0.23 & -0.07 & 44.17 & 0.86 & & & & & \\
\hline VEGE & 0.03 & -0.03 & 3.45 & -0.68 & VEGE & 0.05 & 0.07 & 10.26 & -0.55 & & & & & \\
\hline AREA & 0.06 & 0.01 & 6.06 & -0.57 & AREA & 0.03 & 0.00 & 5.36 & -0.85 & & & & & \\
\hline CFFD & 0.11 & 0.08 & 11.55 & -0.2 & CFFD & 0.08 & 0.01 & 15.38 & -0.41 & & & & & \\
\hline DSTP & 0.15 & 0.08 & 15.86 & 0.37 & CBPD & 0.13 & 0.02 & 24.82 & 0.01 & & & & & \\
\hline
\end{tabular}

$\mathrm{I}$ - contribution of the predictor; $\mathrm{J}$ - interaction between each predictor and the others predictors; $\mathrm{R}^{2}$ - percentage of total explained variance; Z-Score - value of I from randomizations of the data matrix for possible predictors variables that explain the abundance of each species.

Proximity between bodies of water could facilitate migration of individuals between subpopulations, which are sources of colonization when local extinction in some bodies of water occurs (Burne and Griffin 2005, Laan and Verboom 1990, Semlitsch 2000). Furthermore, this dynamic might facilitate dispersion for amphibians that avoid inter- and intra-specific competition or may influence adult habitat choice for bodies of water without predators (Burne and Griffin 2005, Rieger et al. 2004). The use of larger bodies of water with longer hydroperiods or smaller bodies of water with 
shorter hydroperiods is determined by different reproductive adaptations, mainly in regard to larval development and survival (Peltzer and Lajmanovich 2004, Semlitsch 2000). Thus, a landscape with a mosaic of different sized bodies of water and different hydroperiods, along with a surrounding matrix of native vegetation, is ecologically important for the conservation and connectivity of anuran communities among bodies of water, Scinax uruguayus presence is facilitated by near proximity of bodies of water. Since this species is associated with open areas such as natural fields (Garcia et al. 2007), dispersion between nearby bodies of water could facilitate the choice of bodies of water for offspring development, increase genetic exchange among individuals and guarantee the reproductive success of the species (Burne and Griffin 2005).

Less than $0.5 \%$ of subtropical grasslands are protected (MMA 2000), and the rest of the area is private property where agriculture and livestock provide constant and intensive impact and fire is used to renew pastures and eliminate plants with low nutritional value to livestock (Overbeck et al. 2007). Fire is important in maintaining natural fields and the absence of fire, can favor establishment of shrubs in open areas and the advance of forests (Behling and Pillar 2007, Overbeck et al. 2007). Additionally, fire suppression results in the accumulation of flammable organic material and thereby increase the risk of fire (Behling and Pillar 2007) and compromise the survival of forest fragments (Weber et al. 2007). However, care is absolutely necessary to maintain amphibian anuran diversity in fields because fires can have their own impact on the dynamics that maintain anuran diversity in natural field landscapes. Without control, fire to renew pasture can destroy vegetation around bodies of water that frogs use for shelter and calling sites and as corridors by those species that leave day-time shelter in forests or forest fragments (Silva and Rossa-Feres 2007) and for arboreal species that move between nearby bodies of water. Therefore, we recommend that fire in natural fields be used carefully and in a way that preserves vegetation around and within forest fragments. Anuran diversity in the study area was influenced by the proximity of forest fragments and vegetation apparently influences habitat selection by some species, in particular, vegetation in and around bodies of water. Thus, precautions recommended here should preserve the features necessary for anuran reproduction and thus maintain anuran diversity in natural fields.

\section{ACKNOWLEDGMENTS}

Marlon Selusniaki and Rodnei da Silva Gonçalves for help with field work. To Sr. Joaquim Osório Ribas and Sr. Francisco Zani Melo for permission to work on their properties. To the Chico Mendes Institute for Conservation Biodiversity for permission to collect specimens in Conservation Units (License \# 132825). Thanks to Coordenação de Aperfeiçoamento de Pessoal de Nível Superior (CAPES) for the financial support for C.E.C. (PRODOC $\mathrm{n}^{\mathrm{o}} 18$ - 32/2010) and to the Conselho Nacional de Desenvolvimento Científico e Tecnológico (CNPq) for the financial support for D.S.G.

\section{RESUMO}

Padrões de distribuição de anfíbios são conhecidos por serem influenciados pela diversidade do habitat dos sítios de reprodução. Assim, a variabilidade dos sítios de reprodução e o conhecimento de como esta variabilidade influencia a diversidade de anuros é de suma importância. Aqui, nós examinamos quais características dos sítios de reprodução são mais influentes sobre a diversidade de anuros em campos naturais associados à Floresta com Araucária, Sul do Brasil, especialmente em locais de risco devido às atividades antrópicas. Nós avaliamos as associações entre a heterogeneidade de habitats e diversidade de espécies de anuros em nove corpos d'água de setembro de 2008 a março de 2010, totalizando 12 amostragens, as quais 16 espécies foram registradas. Dos sete descritores ambientais analisados, a profundidade da água, a área do corpo d'água e a distância do fragmento 
de floresta mais próximo explicaram $81 \%$ do total na diversidade de espécies. A profundidade da água, o tipo de vegetação no entorno do corpo d'água, a superfície da área e a distância do corpo d'água mais próximo explicaram de $31 \%$ a $74 \%$ da variância na abundância de nove das 16 espécies. Desta forma, a manutenção dos corpos d'água, da vegetação do seu entorno e de fragmentos naturais existentes nos campos, assim como o controle do fogo (utilizado na renovação de pastagens), são de fundamental importância para a manutenção da diversidade de espécies de anuros através da conservação de seus sítios de reprodução.

Palavras-chave: conservação, variáveis ambientais, modelos linear generalizados, partição hierárquica.

\section{REFERENCES}

AFONSO LG AND ETEROVICK PC. 2007. Microhabitat choice and differential use by anurans in forest streams in southeastern Brazil. J Nat Hist 41: 937-948.

BABBIT KJ. 2005. The relative importance of wetland size and hydroperiod for amphibians in southern New Hampshire, USA. Wetl Ecol Manag 13: 269-279.

BABBIT KJ AND TURnER GW. 2000. Use of Temporary Wetlands by Anurans in a Hydrologically Modified Landscape. Wetlands 20: 313-322.

BASTAZINI CV, MundUCURUCA JFV, ROCHA PLB AND NAPOLI MF. 2007. Amphibians from the Restinga of Mata de São João, Bahia, Brazil: which environmental variables are associated with the anuran composition? Herpetologica 63: 459-471.

BEHLING H. 2002. South and southeast Brazilian grasslands during late quaternary times: a synthesis. Palaeogeogr Palaeocl 177: 19-27.

BEHLING H AND PILLAR VD. 2007. Late Quaternary vegetation, biodiversity and fire dynamics on the southern Brazilian highland and their implication for conservation and management of modern Araucaria forest and grassland ecosystems. Philos T Roy Soc B. Biological Sciences 62: 243-251.

BEJA P AND AlCAZAR R. 2003. Conservation of Mediterranean temporary ponds under agricultural intensification: an evaluation using amphibians. Biol Conserv 114: 317-326.

BURNE MR AND GRIFFIN CR. 2005. Habitat associations of pool-breeding amphibians in eastern Massachusetts, USA. Wetl Ecol Manag 13: 247-259.

BURNHAM KP AND ANDERSON DR. 1998. Model selection and inference. Springer, New York.

BURNHAM KP AND ANDERSON DR. 2002. Model selection and multimodel inference: a practical information-theoretic approach, $2^{\text {nd }}$ edition. Springer-Verlag, New York, 488 p.
CAMPOS FS AND VAZ-SILVA W. 2010. Distribuição espacial e temporal da anurofauna em diferentes ambientes no município de Hidrolândia, GO, Brasil Central. Neotrop Biol Conserv 5: 179-187.

CARdoso AJ, Andrade GV AND HAdDAD CFB. 1989. Distribuição espacial em comunidades de anfíbios (Anura) no sudeste do Brasil. Rev Bras Biol 49: 241-249.

CARDOSO AJ AND HADDAD CFB. 1984. Variabilidade acústica em diferentes populações e interações agressivas de Hyla minuta (Amphibia, Anura). Cienc Cult 36: 1393-1399.

CHEVAN A AND SUTHERLAND M. 1991. Hierarchical Partitioning. Am Stat 45: 90-96.

CONTE CE AND Machado RA. 2005. Riqueza de espécies e distribuição espacial e temporal em comunidade de anuros (Amphibia, Anura) em uma localidade de Tijucas do Sul, Paraná, Brasil. Rev Bras Zool 22: 940-948.

Conte CE, Nomura F, Machado RA, Kwet A, Lingnau R AND ROSSA-FERES DC. 2010. Novos registros na distribuição geográfica de anuros na Floresta com Araucária e considerações sobre suas vocalizações. Biot Neotrop 10: 201-224.

Conte CE AND Rossa-Feres DC. 2006. Diversidade e ocorrência temporal da anurofauna (Amphibia, Anura) em são José dos Pinhais, Paraná, Brasil. Rev Bras Zool 23: $162-175$.

CONTE CE AND RosSA-FERES DC. 2007. Riqueza e distribuição espaço-temporal de anuros em um remanescente de Floresta de Araucária no sudeste do Paraná. Rev Bras Zoo 24: 1025-1037.

EGAN RS AND PATON PWC. 2004. Within-pond parameters affect in oviposition by Wood frogs and spotted salamanders. Wetlands 24: 1-13.

Garcia PCA, LaVILla E, LANGONE JA AND SEgalla MV. 2007. Anfíbios da região subtropical da América do Sul: padrões de distribuição. Ciênc Amb 35: 65-100.

GISP - Programa Global DE EsPÉcIES INVASORAS. 2005. América do Sul invadida: a crescente ameaça das espécies exóticas invasoras. Gisp.

GUimarÃes RZ, OliveIRA FA AND GONÇALVES ML. 2010 Avaliação dos impactos da atividade de silvicultura sobre a qualidade dos recursos hídricos superficiais. Sci Forest 38: 377-390.

HAMER AJ AND PARRIS KM. 2011. Local and landscape determinants of amphibian communities in urban ponds. Ecol Appl 21: 378-390.

HaZell D, CunNingnham R, LindenMayer D, Mackey B AND OSBORNE W. 2001. Use of farm dams as frog habitat in an Australian agricultural landscape: factors affecting species richness and distribution. Biol Conserv 102: 155-169.

HERRMANN HHL, BABBIT KJ AND BABER MJ. 2005. Effects of landscape characteristics on amphibian distribution in a forest dominated landscape. Biol Conserv 123: 139-149.

Huston MA. 1994. Biological diversity - the coexistence of species on changing landscapes. New York, Cambridge University press. 
HUTCHINSON GE. 1959. Homage to santa Rosalia or why there so many kinds of animals? Am Nat 93: 145-159.

IAPAR - InSTITUTO AgRONÔMICO DO PARANÁ. 2014. Cartas Climáticas do Paraná. Available in: http://www.iapar.br/ modules/conteudo/conteudo.php?conteudo=863, Acessed on: September 6, 2014.

Keller A, RöDEl MO, LinSEnMair KE AND GRAFE TU. 2009. The importance of environmental heterogeneity for species diversity and assemblage structure in Bornean stream frogs. J Anim Ecol 78: 305-314.

KLEIN RM. 1960. O aspecto dinâmico do pinheiro brasileiro. Sellowia 12: 17-44.

Kwet A. 2000. The genus Pseudis (Anura: Pseudidae) in Rio Grande do Sul, southern Brazil, with description of a new species. Amphibia-Reptilia 21: 39-55.

LAAN R AND VERBOOM B. 1990. Effects of pool size and isolation on amphibian communities. Biol Conserv 54: 251-262.

LichtenBerg JS, King SL, GRACE JB AND WALls SC. 2006. Habitat associations of chorusing anurans in the lower Mississippi river alluvial valley. Wetlands 26: 736-744.

MAACK R. 2012. Geografia Física do Estado do Paraná, $4^{a}$ edição, Ponta Grossa, Editora UEPG.

MAC NALLY R. 1996. Hierarchical partitioning as an interpretative tool in multivariate inference. Aust J Ecol 21: 224-228.

MAC NALLY R. 2000. Regression and model-building in conservation biology, biogeography and ecology: the distinction between - and reconciliation of - 'predictive' and 'explanatory' models. Biodiv Conserv 9: 655-671.

MAC NALLY R. 2002. Multiple regression and inference in ecology and conservation biology: further comments on retention of independent variables. Biodiv Conserv 11: 1397-1401.

McCullagh P AND Nelder JA. 1989. Generalized Linear Models, $2^{\text {nd }}$ edition, Chapman $\&$ Hall, London.

MEDEIROS JD, SAVI M AND BRITO BFA. 2005. Seleção de áreas para criação de Unidades de Conservação na Floresta Ombrófila Mista. Biotemas 18: 33-50.

MMA - Ministério Do MeIo AMBIEnTE. 2000. Avaliação e ações prioritárias para conservação da biodiversidade da Mata Atlântica e Campos Sulinos. Relatório técnico, Brasília, DF, Brasil.

Overbeck GE, Müller SC, Fidelis A, Pfadenhauer J, Pillar VD, Blanco CC, Boldrini II, Both R AND FORNECK ED. 2007. Brazil's neglected biome: The South Brazilian Campos. Perspect Plant Ecol Evol Syst 9: 101-116.

PARRIS KM. 2004. Environmental and spatial variables influence the composition of frog assemblages in subtropical eastern Australia. Ecography 27: 392-400.

PARRIS KM AND MCCARTHY MA. 1999. What influences the structure of frog assemblages at forest streams? Aust J Ecol 24: 495-502.

Peltzer PM And Lajmanovich RC. 2004. Anuran tadpole assemblages in riparian areas of the Middle Paraná River, Argentina. Biodiv Conserv 13: 1833-1842.
Pillar VD, DuArte LDS, Sosinski EE AND JONER F. 2009. Discriminating trait-convergence and trait-divergence assembly patterns in ecological community gradients. J Veg Sci 20: 334-348.

PILlaR VD AND VÉlez E. 2010. Extinção dos Campos Sulinos em unidades de conservação: um fenômeno natural ou um problema ético? Natureza \& Conservação 8: 84-88.

Pinheiro J, Bates D, Debroy S, Sarkar D and R Core TEAM. 2012. nlme: Linear and nonlinear mixed effects models. R package version 3.1-109, Available in: http:// cran.r-project.org/package $=$ nlme.

Pombal JR JP AND HADDAD CFB. 2005. Estratégias e modos reprodutivos em anuros em uma poça permanente na Serra de Paranapiacaba, Sudeste do Brasil. Pap Avuls Zool 45: 201-213.

R Development Core Team. 2012. R: A language and environment for statistical computing. R Foundation for Statistical Computing, Vienna, Austria. ISBN 3-90005107-0. Available in: http://www.Rproject.org.

RANGEl TFLVB, DinIZ-FILHO JAF AND BINI LM. 2006. Towards an integrated computational tool for spatial analysis in macroecology and biogeography. Global Ecol Biogeogr 15: 321-327.

Richter-Boix A, LlóRente GA AND Montón A. 2007. A comparative study of predator-induced phenotype in tadpoles across a pond permanency gradient. Hydrobiologia 583: 43-56.

RIEGER JF, BINCKLEY CA AND RESETARITS JR WJ. 2004. Larval performance and oviposition site preference along a predation gradient. Ecology 85: 2094-2099.

Rossa-Feres DC And Jim J. 2001. Similaridade do sítio de vocalização em uma comunidade de anfíbios anuros na região noroeste do Estado de São Paulo, Brasil. Rev Bras Zool 18: 439-454.

RotheRMEL BB. 2004. Migratory success of juveniles: a potential constraint on connectivity for pond-breeding amphibians. Ecol App 14: 1535-1546.

RotHERMEL BB AND SEMLITSCH RD. 2002. An experimental investigation of landscape resistance of forest versus oldfield habitats to emigrating juvenile amphibians. Biol Conserv 16: 1324-1332.

SANTOS TG, Rossa-Feres DCAND CASATTI L. 2007. Diversidade e distribuição espaço-temporal de anuros em região com pronunciada estação seca no sudeste do Brasil. Iheringia, Serie Zoologica 97: 37-49.

SCOTT JR N AND WoODWARD BD. 1994. Surveys at breeding sites, p. 118-125. In: Heyer WR et al. (Eds), Measuring and monitoring biological diversity, standard methods for amphibians, Smithsonian Institution Press, Washington.

SEMLITSCH RD. 2000. Principles for management of aquatic breeding amphibians. J Wildl Manag 64: 615-631.

Shulse CD, SEMLitsch RD, TRAUTh KM AND Williams AD. 2010. Influences of design and landscape placement parameters on amphibian abundance in constructed wetlands. Wetlands 30: 915-928. 
SILVA FR, CANDEIRA CP AND RosSA-FERES DC. 2012. Dependence of anuran diversity on environmental descriptors in farmland ponds. Biodivers Conserv 21: 1411-1424.

SILVA FR, GIBBS JP AND RossA-Feres DC. 2011a. Breeding Habitat and Landscape Correlates of Frog Diversity and Abundance in a Tropical Agricultural Landscape. Wetlands 31: 1079-1087.

SilvaFR, OLIVEIRA TA, GibBS JP AND ROSSA-FERES DC. $2011 \mathrm{~b}$. An experimental assessment of landscape configuration effects on frog and toad abundance and diversity in tropical agro-savannah landscapes of southeastern Brazil. Landsc Ecol 27: 87-96.

SILVA FR AND ROSSA-FERES DC. 2007. The use of forest fragments by open-area anurans (Amphibia) in northwestern São Paulo State, Brazil. Biota Neotrop 7: 141-148.

SILVA FR AND ROSSA-FERES DC. 2011. Influence of terrestrial habitat isolation on the diversity and temporal distribution of anurans in an agricultural landscape. J Trop Ecol 27: 327-331.

Silva RA, MARTINS IA AND Rossa-Feres DC. 2011. Environmental heterogeneity: Anuran diversity in homogeneous environments. Zoologia 28: 610-618.

SouZA-FILHO GA AND CONTE CE. 2010. Anfíbios de uma área de campo da depressão central do Rio Grande do Sul. Arq Mus Nac 68: 125-134.
VASCONCElos TS, SANTOS TG, ROSSA-FERES DC AND HADDAD CFB. 2009. Influence of the environmental heterogeneity of breeding ponds on anuran assemblages from southeastern Brazil. Can J Zool 87: 699-707.

Venables WN AND RIPLEY BD. 2002. Modern Applied Statistics with S. $4^{\text {th }}$ Edition. Springer, New York.

WALSH C AND MAC NALLY R. 2008. Hier.part - Hierarchical Partitioning. R Package version 1.0-4. Available in: http:// cran.r-project.org/web/packages/hier.part/index.html

WEBER KS, MIRANDA DLC AND SANQUETTA CR. 2007. ANAIS DO VIII CONGRESSO DE ECOLOGIA DO BRASIL, 23 a 28 de Setembro de 2007, Caxambu - MG.

WELLS KD. 2007. The Ecology and behavior of amphibians. The University of Chicago Press, Chicago, 1148 p.

Werner EE, Relyea RA, Yurewicz KL, SKelly DK AND DAVIS CJ. 2009. Comparative landscape dynamics of two anuran species: climate-driven interaction of local and regional processes. Ecol Monogr 79: 503-521.

ZUUR AF, IENO EN, WALKER NJ, SAVELIEV AA AND SMITH GM. 2009. Mixed effects models and extensions in ecology with R. Springer, New York. 